\title{
Suomen ja Neuvostoliiton tieteellinen yhteistyö - ministeri Pekka Kuusen haastattelu
}

YYA-sopimus vahvisti sen muutoksen Suomen ja Neuvostoliiton välisissä suhteissa, joka tapahtui toisen maailmansodan päättyessä. Tänä vuonna vietetään YYA-sopimuksen kolmikymmenvuotisjuhlaa. Juhlavuoden viettäminen ei ole muodollisuus. Juhliminen osoittaa ja samalla kehittää sopimuksen ajankohtaista merkitystä. YYA-sopimus on edelleen luja perusta maidemme välisille suhteille ja yhteistyölle.

YYA-sopimuksen solmimisen jälkeen yhteistyö on laajentunut eri aloille ja samalla syventynyt. Sen tueksi on solmittu erityissopimuksia, jotka konkretisoivat yhteistyön sisällön eri aloilla ja määrittelevät vastuussa olevat elimet.

Tieteen ja tekniikan alalla tärkein kehityslinja on ollut tieteellis-teknisen yhteistyön erityissopimusten solmiminen; ns. TT-yhteistoiminta. Perusasiakirja, "sopimus tieteellis-teknisestä yhteistoiminnasta Suomen Tasavallan ja Sosialististen Neuvostotasavaltain Lïton välillä", allekirjoitettiin vuonna 1955. Tieteellis-teknillisen yhteistyön historiikissa (Väinö Kaukonen: Kaksi vuosikymmentä tieteellis-teknistä yhteistoimintaa Suomen ja Neuvostoliiton välillä, Helsinki 1975) sopimusta valmistelleen Suomen osapuolen työryhmän sihteeri, TT-komitean pitkäaikainen varapuheenjohtaja Väinö Kaukonen jakaa yhteistyön kehityksen kahteen jaksoon: vuosina 1956-1968 tapahtui yhteyksien ja toimintamuotojen kehittelyä, vuosina 1969-1975 toimintamuotojen vakiintuminen. Vakiintumisen tärkeimpänä muotona tieteellisen $y \boldsymbol{h}$ teistyön alalla on ollut eri alojen pysyvien yhteistyöryhmien perustaminen vuodesta 1969 alkaen: ryhmiä on tällä hetkellä neljättäkymmentä. Perustan yhteistyön syvenemiselle ja laadulliselle kehitykselle saavutetulta perustalta antavat pitkän tähtäyksen ohjelmat, joita on laadittu kaksi: vuonna 1974 hyväksyttiin ohjelma teknisille aloille ja vuonna 1975 luonnontieteiden, yhteiskuntatieteiden ja humanististen tieteiden aloille.

Väinö Kaukonen toteaa: "Ensimmäisten toimintavuosien kylläkin monitahoisesta, mutta ensi sijassa tutustumisluonteisesta vuorovaikutuksesta ja vaatimattomista konkreettisista tuloksista Suomen ja Neuvostoliiton välinen tieteellis-teknillinen yhteistoiminta on sopimuksen allekirjoittamisen 20-vuotispäivään saavuttaessa kehittynyt määrätietoiseksi, täsmällisin tavoittein ja yhteisesti sovituin ohjelmin harkittavaksi yhteistyöksi, johon vuosittain osallistuu tiedemies- ja asiantuntijavaihdon puitteissa molemmin puolin yli viisisataa tiedemiestä ja muuta korkean tason asiantuntijaa.'

TT-yhteistyön rinnalla on koulutuksen, tieteen ja kulttuurin aloilla kehittynyt myös muita yhteistyölinjoja. Tutkimuksen kannalta näistä ovat tärkeimpiä opetusministeriön ja Suomen akatemian kautta tapahtuva vaihto, maidemme välisen taloudellisen yhteistyön monet muodot sekä eräät erillissopimukset (mm. oikeudellisen alan ja terveydenhuollon sopimukset) (kts. esim. Rolf Hernberg (toim.): Tiede - tekniikka - yhteistyö, suomalais-neuvostoliittolainen seminaari, TTKK, Tampere 1977; julkaisuun sisältyy luettelo Suomen ja Neuvostoliiton välillä tehdyistä yhteistyösopimuksista ja -pöytäkirjoista, jotka sivuavat tieteellis-teknistä yhteistyötä).

Suomen ja Neuvostoliiton välinen yhteistyö on sekä yleisesti, YYA-sopimuksen pohjalta, että erillisaloilla ainutlaatuista sosialistisen ja kapitalistisen maan välillä. Sopimusten ja konkreettisten saavutusten kokonaisuus edusti ETYK:n päätösasiakirjan periaatteita jo ennen ETYK:ä. Nyt on erityisen tärkeätä ponnistella yhteistyön edelleen kehittämisen puolesta; siitä hyötyvät molemmat osapuolet ja se on keskeinen tie toimia koko kansainvälisen jännityksen lientymisen puolesta.

Tieteellis-teknisen yhteistoimintakomitean Suomen osapuolen puheenjohtajana on vuodesta 1974 lähtien toiminut ministeri Pekka Kuusi. Tiede- ja edistys -lehti pyysi ministeri Kuuselta haastattelun selvittääkseen yhteistyön lähiajan kehitysnäkymiä sekä niitä mahdollisuuksia, joita se avaa suomalaisen tieteen kehitykselle ja suomalaisille tutkijoille. 
$T \& E$ : Useassa yhteydessä on korostettu sitä, että Suomen ja Neuvostoliiton ystävyys- ja yhteistyösuhteet muodostavat yhtenäisen kokonaisuuden. Voiko nimenomaan tieteellis-teknisen $y h$ teistyön roolia tässä jotenkin täsmentää?

Ku usi: - Tieteellis-tekninen yhteistyö Suomen ja Neuvostoliiton välillä alkoi vuonna 1955 , kuten Väinö Kaukonen toteaa, tunnustelunomaisesti. Tieteellis-tekninen kehitys luo perustaa taloudelliselle ja kaupalliselle yhteistyölle, ja näin on varsin luonnollista, että juuri tieteellistekninen yhteistyö on ollut YYA-sopimuksen ensimmäinen varsinainen systemaattinen sovellutusalue. Suomen puolelta työ alkoi verraten varovaisesti. Teollisuuden puolella oli aluksi epäluuloja tämän toiminnan luonteeseen nähden. Oli sittenkin luonnollisempaa, että puhtaan tieteen harjoittajat osoittivat suurempaa valmiutta Suomen ja Ner vostoliiton väliseen tieteelliseen kanssakäymi :een. Jo 1950-luvun kestäessä ja etenkin 1960-1uvulla ennakkoluulottomuus työtä kohtaarı lisääntyi kuitenkin selvästi, ja siten viime v' osikymmenen jälkipuoliskolla oli jo varsin hyvät edellytykset syventää yhteistyötä. Päästiin aloittamaan varsinaisten pysyvien työryhmien kehittely, mikä vasta on antanut edellytykset sille laajalle ja yksityiskohtaiselle yhteistyölle, mikä 1970-luvulla on vakiintunut.

Tällä hetkellä työskentelee yli 30 työryhmää omilla aloillaan varsin kiinteästi yhteiskokouksia, seminaareja ja symposiumeja järjestäen sekä asiantuntijavaihtoa kehittäen. Tämä on luonut niin mittavan tieteenharjoittajien ja teollisuusmiesten keskinäisen kanssakäymisen, että epäilemättä tämän kaltaisella yhteistyöllä on niin tieteen kuin talouden ja kaupankäynninkin kannalta olennainen merkitys. Ehkä vielä tätäkin tärkeämpää on se, että keskeinen tieteen ja talouden harjoittajien piiri on tottunut jatkuvaan luottamukselliseen yhteistyöhön Neuvostoliiton vastaavien elinten kanssa.

Komitean Suomen puolen puheenjohtajana olenkin korostanut tämän yhteistyön varsin eh- jää poliittista merkitystä. Suomen ja Neuvostoliiton johtohenkilöiden jatkuva luottamuksellinen kanssakäyminen tieteen, talouden ja kaupan aloilla johtaa siihen, että maidemme keskinäissuhteiden ilmapiiri jo tästä syystä muodostuu kokonaan toisenlaiseksi kuin mitä se oli joskus 1930-luvulla. Yhteistyöstä on tullut jatkuvaa arkipäivän elämää, ja näin juuri naapureiden kesken pitääkin olla.

$T$ \& E: Äskettäin on hyväksytty pitkän tähtäyksen ohjelmat, ja työryhmäorganisaatio täydentyy jatkuvasti. Millaisia tehtäviä yhteistyön kehittäminen asettaa lähitulevaisuudessa?

Kuusi: - Tieteellis-teknisessä yhteistyössä Suomella on vastapuolenaan toisaalta Neuvostoliiton ministerineuvoston alainen tieteen ja tekniikan valtionkomitea, toisaalta Neuvostoliiton tiedeakatemia. Tästä syystä ohjelmatkin on jaettu kahteen osaan siten, että on kaksi pitkän tähtäyksen ohjelmaa, joiden allekirjoittajana toisessa tapauksessa on tieteen ja tekniikan valtionkomitea, toisessa tapauksessa sekä valtionkomitea että tiedeakatemia. Nämä ohjelmat kirjaavat yhteistyön tähänastisen kehityksen. Samalla niissä on inventoitu tärkeimmät aiheet, joiden on arvioitu tulevan esiin lähimmän vuosikymmenen kuluessa.

Pitkän tähtäyksen ohjelmiin pyrittiin nimenomaan sijoittamaan uusia mielenkiintoisia aiheita myös yhteiskuntatieteiden aloilta. Toistaiseksi olemme käytännössä harjoittaneet verrattain vähän yhteistyötä taloustieteen, sosiologian, psykologian ja valtio-opin aloilla, mutta näidenkin piirissä on yhteistyö ohjelmien hyväksymisen jälkeen edennyt. Ensimmäiset pidetyt seminaarit ja valtuuskuntien kokoukset osoittavat, että mielenkiintoa puolin ja toisin tunnetaan yhteistyön kehittämiseen myös näillä aloilla.

Luonnollisesti yhteiskuntajärjestelmiltään erilaisten maiden tutkijoiden näkökulmat esimerkiksi sosiologian tai taloustieteen ongelmiin ovat erilaiset. Mielenkiintoa tällä hetkellä herättää se, että yhteiskunnan muutoksessa näyttää ole- 
van lainalaisuuksia, jotka ovat siinä määrin ihmisen peruskäyttäytymiseen liittyviä, että ne ovat järjestelmästä riippumattomia; monet yhteiskunnan muutokset sen sijaan ovat selvästi järjestelmäsidonnaisia. Yhteistyön luonnollinen tavoite tuntuisi olevan näiden erilaatuisten prosessien erottaminen toisistaan. Lienee vielä ennenaikaista arvioida, kuinka nopeasti tällainen eri yhteiskuntajärjestelmiä edustavan kahden maan tutkijoiden välinen yhteistyö voi saavuttaa tuloksia.

Mielenkiintoista on ollut myös todeta, että kun vuosi sitten hyväksyttiin ainutlaatuinen, vuoteen 1990 asti ulottuva pitkän ajanjakson ohjelma taloudelliselle yhteistyölle, tähän ohjelmaan liittyi olennaisena osana myös tieteellistekninen tutkimus ja yhteistyö. Talousohjelmaa varten kartoitettiin molemmin puolin varsin ykyksityiskohtaisesti niin perinteisillä yhteistoiminnan aloilla kuin aikaisemmin yhteistoiminnan ulkopuolelle jääneillä aloilla mahdolliset konkreettisen yhteistyön kohteet. Nämä sisällytettiin ohjelmaan.

Mutta ei tässä kyllin. Talousohjelmahan edellyttää suomalais-neuvostoliittolaisessa yhteistyössä toistaiseksi laajamittaisesti kokeilemattomien yhteistyömuotojen mukaantuloa mm. teollista ja tuotannollista yhteistyötä, yhteistuotantoa, yhteistä markkinointia kolmansiin maihin jne. Jo viime vuonna virisi maidemme välillä käydyissä keskusteluissa ajatus, että pitkän ajanjakson talousohjelman tehokas käynnistäminen edellyttää yhteistyömenetelmien nykyistä huolellisempaa selvittämistä. Syksyllä aloitettiin neuvottelut yksityiskohtaisesta metodologisesta selvitystyöstä, jonka tavoitteena on nimenomaan tutkia maidemme välisen yhteistyön menetelmiä. Tavoitteena on laatia työmenetelmien malli- ja ohjekirja, joka pyritään tekemään niin yksityiskohtaiseksi ja konkreettiseksi, että jokainen yritys ja tutkija, joka haluaa ryhtyä yhteistyöhön toisen maan vastaavien edustajien kanssa, löytää siitä ohjeita. On tärkeätä selvittää hyvinkin konkreettisesti esiintyvät ongelmat, jotta tarpeettomalta kitkalta vältytään.

Selvitystyö on vuoden alussa käynnistynyt, ja molemmissa maissa on osoitettu hyvin suurta mielenkiintoa sitä kohtaan. Neuvostoliitossa ovat tieteen ja tekniikan valtionkomitea, eri ministeriöt, systeemitutkimuksen instituutti, maailmantalouden ja kansainvälisten suhteiden instituutti, jopa Gosplan, asettaneet työvoimaa ja resursseja selvitykseen. Myös Suomessa toimii varsinaisen työryhmän tukena laaja asiantuntijoiden piiri. Oletamme, että työn tuloksena saamme konkreettisten aineistojen lisäksi myös osviittoja yhteistyön kehittämiseksi yleisemminkin.

Kuluneiden runsaan kahden vuosikymmenen aikana Suomen ja Neuvostoliiton tieteellis-tekninen yhteistyö on paljolti kehittynyt ikään kuin omalla painollaan. Ei ole ehkä riittäı_̌̉sti pysähdytty tutkimaan itse tämän työn ment, , Imiä ja niiden kehittämistä. On aika todella pitä: huolta siitä, että Suomen ja Neuvostoliiton pioneerikokemukset tulevat menetelmiltäänkin huolellisesti arvioiduiksi. Tämän tapaisella metodolog1sella selvityksellä saattaa olla heijastusvaikutuksia kansainvälisen yhteistyön kehittämiseen.

Yleisesti Suomi tietenkin pyrkii hyötymään asemastaan Neuvostoliiton pienenä naapurimaana, mutta on nähtävä myös tämän asian poliittinen puoli. Suomi kykeni ETYK:n edellä toimimaan eräänlaisena Euroopan kärkimaana. Samalla tavoin meillä on tiettyjä edellytyksiä toimia yhteistyömenetelmien yleisen kehittämisen hyväksi. Neuvostoliiton puolelta osoitettu harrastus juuri yhteistyömenetelmien kehittämiseen on rohkaissut siten, että vuoden 1978 aikana komitean suomalainen osapuoli tulee keskittämään erityisen huomionsa tähän aihepiiriin.

$T$ \& E:Hyväksytyissä pitkän tähtäyksen yhteistyöohjelmissa on esitetty hyvin konkreettisia muotoja tulevalle työlle, näistä pisimmälle menevänä varsinaisten yhteistutkimusten käynnistäminen yhteisistä aiheista. Onko näiden 
konkreettisten muotojen kehittämisestä jo olemassa suunnitelmat?

Kuusi: - Pitkän tähtäyksen ohjelmien seuranta on pyritty järjestämään erikseen ns. tieteellisten työryhmien ja erikseen ns. teknistaloudellisten ryhmien osalta. On pakko todeta, että toistaiseksi ei olla päästy vielä kummankaan ohjelman konkreettisessa kehittelyssä kovinkaan pitkälle. Moskovassa pidetään lähiaikoina jälleen seurantaryhmän kokous. Toivottavasti siellä kyetään asettamaan myös tieteellisille kohteille aikaisempaa sitovammin aikaan sidottuja tavoitteita. Tähän asti siinä ei olla mielestäni aivan riittävästi onnistuttu.

Kaikissa työryhmien yleiskokouksissa on tarkoitus käsitellä kysymystä. Huomiota on kiinnitettävä siihen, miten kukin työryhmä voisi edistää juuri sille kuuluvien yhteistyöohjelmissa esitettyjen tavoitteiden toteutumista. Toivomme, että edistystä tulisi tapahtumaan. Toisaalta on nähtävä, että ohjelmissa esitetyt tavoitteet ulottuvat varsin pitkälle tulevaisuuteen.

$T \&$ E: Suomen puolella tutkimusta sivuavasta yhteistyöstä Neuvostoliiton kanssa huolehtii eri sopimusten perusteella usea elin. Millaiset näiden keskinäiset suhteet ovat?

Kuusi: - Tieteellistekninen yhteistoimintakomitea kattaa organisaationa varsin huomattavan osan suomalais-neuvostoliittolaisesta tieteellisestä yhteistyöstä, mutta tämän organisaation tarkoitus ei suinkaan ole monopolisoida tutkimustyötä. Päin vastoin, kun esimerkiksi jokin korkeakoulu on päässyt tietyn tutkimuksen yhteydessä jatkuvaan, kiinteään yhteistyöhön vastaavan neuvostoliittolaisen yksikön kanssa, niin suosimme välittömien kontaktien ylläpitämistä. Monet suomalaiset teollisuusyritykset ovat kyenneet kehittämään vastaavan neuvostoliittolaisen organisaation kanssa pysyvää yhteistyötä, joka jatkuu TT-komitean asianomaisen työryhmän tieten ja tukemana, mutta ei suinkaan kontrolloimana.

TT-komitea on siis nähdäkseni varsin tehokas yleismenetelmä kontaktien solmimiseksi, ja myöskin jatkuvien yhteyksien ylläpitämiseksi. Mutta kun pyritään jatkuvaan, syvempään tutkijoiden kanssakäymiseen, tämä pitää pyrkiä rakentamaan pysyvälle ja rahoitukseltaankin kestävälle perustalle. Korostan sitä, että TTorganisaatio ei ole Suomen puolella tutkimusta pysyvästi rahoittava, vaan yhteyksiä luova ja ideoita kehittelevä organisaatio. Pyrkimyksenä on, että yhteistyön kohteena oleva tutkimus olisi johdonmukainen osa Suomen tutkimuksesta ja saisi näin rahoituksensa tavanomaisia rahoituskanavia käyttäen.

Suomen akatemialla on omat, välittömät kontaktinsa Neuvostoliiton tiedeakatemiaan, ja niillä on luonnollisesti keskeinen sija Suomen akatemian kansainvälisissä suhteissa. Tietty määrä stipendiaatteja lähetetään akatemian rahoituksella vuosittain Neuvostoliittoon.

Myös opetusministeriöllä on omat kontaktinsa Neuvostoliiton vastaaviin ministeriöihin, ja eri tasoista yhteistyötä korkeakoulujen välillä harjoitetaan juuri opetusministeriön johdolla. Edelleen totean, että sosiaali- ja terveysministeriö on solminut yhteistyösopimuksen Neuvostoliiton vastaavan ministeriön kanssa. Etenkin terveydenhuoltoon liittyvän tutkimusyhteistyön järjestäminen on osoittautunut joustavaksi tämän sopimuksen nojalla.

TT-organisaatio pyrkii olemaan ennen muuta suuri palveluorganisaatio, joka tekee työtä saadakseen yhteistyön niin tehokkaaksi ja tiiviiksi kuin mahdollista. Emme suinkaan halua olla tällä alalla ikään kuin kaikkivaltiaita, vaan pidämme suotavana, että muodostuu moninaisia välittömiä kontakteja tutkijoiden ja yhteisöjen välille.

Myös maidemme välinen talouskomissio on luonnollisesti organisaatio, joka on hyvin lähellä tieteellis-teknistä yhteistoimintakomiteaa. Sen piirissä on perustettu mm. työryhmiä, joiden toiminta osuu lähelle TT-komitean vastaavia työryhmiä. Tieteellis-teknisen yhteistyön eräänä 
tehtävänä onkin nähtävä palvella taloudellisen yhteistyön kehittymistä ja syvenemistä. Jo tähänkin mennessä on voitu siirtää joitakin konkreettisia saavutuksia TT-organisaatiolta talouskomissiolle.

$T \& E$ : Voisitteko jotenkin yleisesti luonnehtia TT-yhteistyön merkitystä Suomen tieteelliselle elämälle; millaisia mahdollisuuksia se avaa?

Ku usi : - Tähän kysymykseen on vaikea antaa yleisluonteista vastausta. Minuun henkilökohtaisesti on tehnyt erittäin suuren vaikutuksen nähdä, miten suuresti neuvostoyhteiskunnassa arvostetaan tiedettä. Tämä osoittaa havainnollisesti sen, miten marxilainen yhteiskuntakäsitys nojaa tieteeseen ja tekniikkaan ihmisen tarpeiden tyydyttäjänä.

Yhteistyön tähänastinen merkitys vaihtelee eri tieteenaloilla. Toistaiseksi varsinaisen tutkimuksellisen yhteistyön aiheita on ollut verrattain vähän. Etenkin luonnontieteiden piirissä on meneillään joitakin korkeatasoisia tutkimustöitä, mutta monien työryhmien kohdalla toiminta on toistaiseksi ollut verraten yleisluontoista. Toivottavasti eri alojen työryhmät tulevat osoittautumaan uudistuskykyisiksi, ja kykenevät esittämään uusia aloitteita yhteistyön kehittämiseksi.

On ilmeistä, että vahvistetut pitkän tähtäyksen ohjelmat sekä talousohjelman pohjalta käynnistynyt metodologian kartoitus tulevat nostamaan yhteistyön ambitiotasoa. Näin voidaan päästä tilanteeseen, jossa nuoret lahjakkaat tutkijat molemmista maista pääsevät joustavasti keskenään kontakteihin.

$T \& E$ : Voisiko sopimusten merkitystä jotenkin arvioida yksityisen tutkijan näkökulmasta?

Ku usi: - Tutkijoita on käynyt tehtyjen sopimusten pohjalta Neuvostoliitossa yhä enemmän — tämä on toistaiseksi ollut meidän kannaltamme yhteistyön päämuoto. Kokemukset ovat sekä varsin tyydyttäviä että osaksi myös epätyydyttäviä. Pelkkä oleskelu jossakin toisessa tutkimuslaitoksessa ei aina riitä.

Työryhmäorganisaation konkreettisten aiheiden kirjaaminen pitkän tähtäyksen ohjelmiin on johtanut kiinnostuksen lisääntymiseen tutkijoiden keskuudessa. Myös kielitaito paranee - tämäkin on eräs yhteistyön edellytys.

$T \& E:$ TT-yhteistyötoimintakomitean Suomen osapuoli voi ilmeisesti toimia myös yksityisten tutkijoiden kontaktien välittäjänä?

Kuusi: - Kyllä. TT-komitean keskeisenä tavoitteena on auttaa tutkijoita nimenomaan solmimaan kontakteja neuvostoliittolaisiin tutkijoihin ja löytämään ne laitokset ja instituutit, joissa tehdään työtä kiinnostavista aihepiireistä. Työryhmäorganisaation laajennuttua nyt lähes kaikki tieteen alat kattavaksi, on se toimiva instrumentti molempien maiden tutkijoiden välisten kontaktien ylläpitämiseksi ja jär’’estämiseksi. TT-komitealle voi tehdä aloitteita yksityinenkin tutkija, mutta työryhmien aloilla yhte stoiminta järjestetään niiden organisaation kautta.

Korostaisin vielä kerran käynnissä olevan metodologisen selvitystyön merkitystä. Sen tavoitteena on saada aikaan kartoitus molemmin puolin tieteellisten laitosten organisaatiosta ja eri laitosten yhteistyömahdollisuuksista. Toistaiseksi molemmissa maissa tunnetaan vielä liian heikosti yhteistyökumppanin järjestelmä. Metodologiaselvityksen eräänä tavoitteena on luoda hyvin käytännöllisluonteinen apumenetelmä yhteyksien tiivistämiselle.

$T \&$ E: Voidaanko Teidän mielestänne olla tyytyväisiä TT-komitean asemaan omassa tieteellisessä yhteisössämme, sen yhteyksiin suomalaisiin tutkijoihin tällä hetkellä?

Ku usi: - Kiinnostus yhteistyötä kohtaan on selvästi nousussa. Tämä ilmenee $\mathrm{mm}$. siinä, että eri alojen yhteistyöryhmien jäsenyyksistä on viime vuosina ollut paljon ylikysyntää. Kiinnostuksen lähtökohtana on varmasti vilpitön halu tutustua naapurimaan tieteelliseen elämään ja solmia kontakteja sen tutkijoiden kanssa. On hyvä, että työryhmien jäseniä voidaan myös vaihtaa; yhä useammat kokeneet tutkijat pääsevät täten 
välittömiin kontakteihin Neuvostoliittoon päin.

Nykyään ei enää myöskään tapaa sellaista epäluuloisuutta TT-yhteistyötä kohtaan, jota vielä 1960-luvullakin oli havaittavissa. Suomessa oivalletaan nykyään laajasti tämän toiminnan edullisuus. Meidän maamme kehitykselle on ainoastaan eduksi, jos kykenemme säilyttämään myös tieteellis-teknisellä alueella sen eräänlaisen suosituimmuusaseman, joka meillä on Neuvostoliiton naapurina mm. ulkomaankaupan suhteen ollut.
Tietenkin yhteistyötä arvioitaessa poliittinen puoli painaa eniten. YYA-sopimus on muodostanut perustan kestävälle yhteistyölle, joka on saanut vakiintuneita muotoja ja muodostunut pysyväksi. Tämä on paras tapa meille osallistua rauhan ja turvallisuuden lujittamiseen niin omassa maanosassamme kuin koko maailmassa. Tätä mallia voitaisiin varmasti soveltaa yleisemminkin.

$T \&$ E: Kïtämme sydämellisesti haastattelusta.

\section{tiede edistys}

Vuoden 1977 numeroita on vielä rajoitetusti saatavissa; numeroiden hinta on 10:- mk, koko vuosikerran tilaukset 30:- mk. Lehdet toimitetaan postiennakolla, tilaukset osoitettava Tutkijaliiton toimistoon, Erottajankatu 5 A 2, 00130 Helsinki 13.

Numeroiden tărkeimmăt artikkelit ovat seuraavat:

1.77 Inkeri Lehtinen, Toivo Karvonen, Kaarlo Tuori, Matti Viikari, Pertti Rovamo: Tuure Lehén 1893-1976.

A. D. Ado: Biologinen ja yhteiskunnallinen "ihmisen ekologiassa".

Pekka Arinen: Biologismi ja inmistieteet.

Pekka Kosonen: Loogisen ja historiallisen suhde kapitalismiteoriassa.

Vesa Oittinen: Spinozan ajankohtaisuudesta.

Kettil Bruunin haastattelu - Kokemuksia 70-Iuvun tiedepolitiikasta.

Orlando Letelier: "Chicagon pojat" Chilessă.

Risto Eräsaari: WFSW 30 vuotta.

Pasi Falk: Marxismin klassikoiden suomennosten historiikkia.

2.77 Eino Karhu: A. I. Arwidssonin aateperinnön historiallinen merkitys.

Risto Alapuro: Marxilaisen yhteiskuntatutkimuksen linjoja Suomessa 1900-50.

Juha Manninen, Kari Sallamaa, Seppo Toiviainen: Kommentteja Alapuron esitelmăăn.

Lauri Hannikainen: ETYK:in păătösasiakirja ja kansainvălinen oikeus.

Michael Wolff: Newtonin mekaniikan tausta.

Antero Tiusasen haastattelu - "Păăoman" kolmannen kirjan suomentamisesta.

Arnold Bruns: Virkakiellosta "Teoriakieltoon"? - Marburgin tapaus.

Yrjö Haila: Tiedettä on puolustettava.

J. P. Roos: Elämäntapatutkimusta ja sosiaalipolitiikkaa Neuvostoliitossa.
3.77 Seppo Toiviainen: Leninismi metodina eli politiikka ja dialektiikka.

Olli järvinen: Biologinen evoluutio.

Matti Saraste: Elămăn synnyn kemia.

Seppo Kuusela, Esa Ranta: Ihmistyminen.

Kari Toikka, Matti Viikari: Suomen työvăenliikkeen historian tutkimuksen kysymyksiả I. Jorma K. Miettinen: Pugwashin nykyinen toiminta.

Bruno Bärs, Jorma Lindfors: Neutronipommin toimintaperiaate ja vaikutukset.

4.77 Erhard Stölting: Tieteen yhteiskunnallinen kuva ja kokonaisyhteiskunnallinen uusintaminen.

Karl Lagerspetz: Luonnontieteet, materialismi ja positivismi.

Yrjö Haila: Mihin ympäristökeskustelu tulisi kohdentaa?

Pekka Nuorteva: Ympäristökeskustelu olisi kohdennettava ekokatastrofikysymykseen.

Kari Toikka, Matti Viikari: Suomen työväenliikeen historian tutkimuksen ongelmia II. Itsenăinen maa - itsenăinen kirjallisuus Esko Ervastin (1921-1977) haastattelu.

Seppo Toiviainen: Todor Pavlov (1890-1977). Antti Kasvio: Teesejä tutkinnonuudistuskeskusteluun. 